\title{
Programa de triagem auditiva neonatal: associação entre perda auditiva e fatores de risco $* * * * *$
}

\author{
Newborn hearing screening program: association between hearing \\ loss and risk factors
}

\author{
Priscila Karla Santana Pereira * \\ Adriana de Souza Martins ** \\ Márcia Ribeiro Vieira *** \\ Marisa Frasson de Azevedo ****
}

\section{* Fonoaudióloga. Mestranda em Distúrbios da Comunicação Humana pela Universidade Federal de São Paulo. Endereço para correspondência: Avenida São João, 1588 - Apto. 67 São Paulo - SP - CEP 01211-000 (priksp@yahoo.com.br).}

**Fonoaudióloga. Especialização em Distúrbios da Comunicação Humana pela Universidade Federal de São Paulo.

***Fonoaudióloga. Aprimoramento em Audiologia Clínica pelo Hospital das Clínicas de São Paulo.

****Fonoaudióloga. Doutora em Distúrbios da Comunicação Humana pela Universidade Federal de São Paulo. Professora Associada do Curso de Fonoaudiologia da Universidade Federal de São Paulo.

*****Trabalho Realizado na Universidade Federal de São Paulo.

Artigo de Pesquisa

Artigo Submetido a Avaliação por Pares

Conflito de Interesse: não

Recebido em 21.09.2006.

Revisado em 07.11.2006; 11.04.2007; 12.07.2007.

Aceito para Publicação em 18.07.2007.

\begin{abstract}
Background: hearing loss in newborns. Aim: to verify the prevalence of auditory alterations in newborns of Hospital São Paulo (hospital), observing if there are any correlations with the following variables: birth weight, gestational age, relation weight/gestational age and risk factors for hearing loss. Method: A retrospective analysis of the hospital records of 1696 newborns; 648 records of preterm infants and 1048 records of infants born at term. All of the infants had been submitted to an auditory evaluation consisting of: Transient Otoacoustic Emissions, investigation of the cochleal-palpebral reflexes and acoustic imittance tests, identifying the type and level of hearing loss. Results: sensorineural hearing loss was identified in $.82 \%$ of the infants who were born at term and in $3.1 \%$ of the preterm infants - with a statistically significant difference. Conductive hearing loss was the most frequent type of hearing loss in both groups, occurring in $14.6 \%$ of the term infants and in $16.3 \%$ of the preterm infants. Alteration of the central auditory system was considered as a possible diagnosis for $5.8 \%$ of the preterm infants and for $3.3 \%$ of the term infants. For the group of infants who were born at term, a significant correlation was observed between failure in the hearing screening test and the presence of risk factors such as family history and presence of a syndrome the child who presented a syndrome had 37 times more chances of failing in the hearing screening test and seven times more chances of failing in the right ear when there was a family history for hearing loss. The lower the gestational age $(<30$ weeks) and birth weight $(<1500 \mathrm{~g})$, the higher the chances of failing in the hearing screening test ( 3 times more). Conclusion: hearing loss had a higher occurrence in preterm infants who remained in the ICU. Gestational age and birth weight were important variables related to the possibility of failure in the hearing screening test. A correlation was observed between the presence of a syndrome and sensorineural hearing loss in infants who were born at term.
\end{abstract}

Key Words: Hearing Loss; Screning; Risk Factors; Prevalence.

\section{Resumo}

Tema: perda auditiva em neonatos. Objetivos: verificar a prevalência de alterações auditivas em neonatos do Hospital São Paulo, observando se há correlação com as variáveis: peso de nascimento, idade gestacional, relação peso e idade gestacional e fatores de risco para deficiência auditiva. Método: realizou-se uma análise retrospectiva dos prontuários de 1696 recém nascidos, sendo 648 nascidos pré-termo e 1048 a termo. Todas as crianças foram submetidas à avaliação audiológica constituída por pesquisa das emissões otoacústicas transientes e do reflexo cocleopalpebral e medidas de imitância acústica, estabelecendo-se o diagnóstico do tipo e grau de perda. Resultados: a perda auditiva neurossensorial foi identificada em $0,82 \%$ das crianças nascidas a termo, e $3,1 \%$ das crianças pré-termo (com diferença estatisticamente significante). A perda auditiva condutiva foi a mais freqüente nas duas populações sendo observada em $14,6 \%$ das crianças nascidas a termo e $16,3 \%$ das crianças pré-termo. Houve suspeita de alterações do sistema auditivo central em 5,8\% das crianças pré-termo e $3,3 \%$ das crianças a termo. Na população de crianças nascidas a termo, houve correlação significante entre falha na triagem auditiva e os riscos antecedente familiar e síndrome, sendo 37 vezes maior a chance de uma criança com síndrome falhar na triagem e sete vezes maior a chance de falhar na orelha direita quando esta tiver antecedente familiar de perda auditiva. Quanto menor a idade gestacional (<30 semanas) e o peso ao nascimento $(<1500 \mathrm{~g})$, três vezes mais chance de falhar na triagem auditiva. Conclusões: houve maior ocorrência de perda auditiva nas crianças pré-termo de UTI neonatal. A idade gestacional e o peso de nascimento foram variáveis importantes relacionadas na probabilidade de falha na triagem auditiva. Houve correlação entre o fator de risco síndrome e a perda auditiva neurossensorial em crianças nascidas a termo.

Palavras-Chave: Perda Auditiva; Triagem; Fatores de Risco; Prevalência.

Referenciar este material como:

PEREIRA, P. K. S.; MARTINS, A. S.; VIEIRA, M. R.; AZEVEDO, M. F. de. Newborn hearing screening program: association between hearing loss and risk factors 1 (original title: Programa de triagem auditiva neonatal: associação entre perda auditiva e fatores de risco). Pró-Fono Revista de Atualização Científica, Barueri (SP), v. 19, n. 3, p. 267-278, jul.-set. 2007. 


\section{Introduction}

The anatomic and physiological integrity of the hearing system, such on its peripheral portion as on its central portion, constitutes a prior requisite to the language normal acquisition and development (Azevedo,1996).

This way, the impact of the hearing loss that is not detected during language development and child socialization stimulated the creation of neonatal hearing screening programs (NHS).

The precocious identification programs of hearing impairment are being developed in Brazil since the eighties with high and low risk populations, using behavioral and electrophysiological procedures. (Castro Junior et al. 2002).

Since 1987 it is being developed in the Federal University of São Paulo (UNIFESP) a program of prevention and precocious identification of peripheral and central auditory alterations (Castro Junior et al., 2002).

In this program, at birth, at the time of leaving the hospital, the auditory universal screening is carried through by means of the transient otoacoustic emissions (TOAE) and search of the algebra cochlea reflex (PCR), since the accomplishment of the hearing screening only in children with some risk factor, will only identify to $40 \% 50 \%$ of the children with significant hearing loss (Chapchap and Segre 2001). If the newborn passes in the hearing screening and it does not have risks for gradual hearing loss or for retro cochlear hearing loss, an orientation is made about the development of hearing and language. Otherwise, it is followed by a multidisciplinary team and periodic evaluations during the first two years of life are carried through.

In case that the newborn fails the test, the otoscopic test and the tympanometric curve are carried through in order to verify if the fail occurred because of conductive alteration. In case that the conductive impairment is proven, the newborn is directed for the otorhinolaryngological examination, being later retested. (Azevedo, 2004)

In case that the fail is not recurrently from some problem of external or middle ear, a complete audiology evaluation is carried through, because of the suspicion of sensorioneural hearing loss. If the sensorioneural hearing loss is confirmed, the intervention (election and adaptation of hearing aid, family orientation and Speech- Language therapy immediately is carried through. The use of hearing aid before the sixth month of life will allow to the child a language development (receptive or expressive), as well as its social development, comparable to the ones of normal children of the same age. (Yoshinada-Itano et al., 1998)

However, in newborns that present risk of retro cochlear alteration, the audiology evaluation is completed including the research of the effect of suppression of the TOAE and evoked auditory Potential of encephalic trunk (PEATE). (Azevedo, 2004)

The newborns that remained in Intensive Care (IC), even that they pass in the hearing screening, they are followed during the three first years of life by the multidisciplinary team that monitories the neuro-psycho-motor development, hearing and language development, and receive fast intervention in the area where there is necessity. (Azevedo, 2004)

This program has as objective to identify the peripheral and central auditory impairment and to intervene as quickly as possible trying to prevent or to minimize future alterations. (Azevedo, 2004)

This way, the behavioral evaluation during the first year of life together with the electrophysiological tests (TOAE and PEATE) makes possible the precocious diagnosis of the hearing disorders in such a way regarding to the auditory acuity, as to the auditory processing. (Castro Junior et al.; 2002)

The audiology diagnosis (identification of the peripheral and central hearing loss) carried through during the first year of life makes possible the medical and speech-language pathology intervention, still in this critical period, that is, the period of maturation and functional plasticity of the Central Nervous System, preventing future alterations and allowing a prognostic more favorable in relation to the global development of the child. (Yoshinada-Itano et al., 1998).

From these considerations, this work had as objective: to verify and to analyze the prevalence of auditory alterations in a population of newborns of the São Paulo Hospital, observing whether there is a correlation with the variables: weight at birth, gestational age, relation weight and gestational age (AIG- adjusted for gestational age, SGA - small for gestational age and BGA - big for gestational age) and risk factors. Moreover, to verify if the prevalence of hearing loss for this population is in accordance with the international and Brazilian prevalence found in literature. 


\section{Method}

The present study was analyzed and approved by the Committee of Ethics in Research of the Hospital São Paulo/ Universidade Federal de São Paulo (Federal University of São Paulo) in 28/11/ 2003 under protocol $n^{\circ} 1440 / 03$. The research was financed by the Conselho Nacional de Desenvolvimento Científico e Tecnológico - CNPq (National Council of Scientific and Technological Development - CNPq) and awardees as better work

FIGURE 1. Distribution of the risks for hearing loss in the Group I (PTNB).

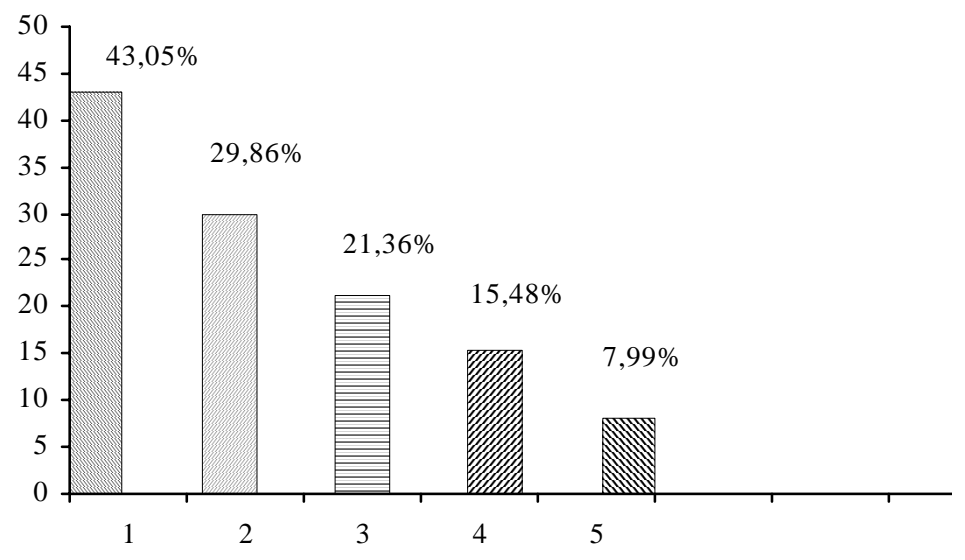

low/small weight for gestacional age (SGA) 圈 ototoxic

层 mechanical ventilation hyperbilirrubinemy

ventricular hemorrhage

FIGURE 2. Distribution of the risks for hearing loss in the II group (TNB).

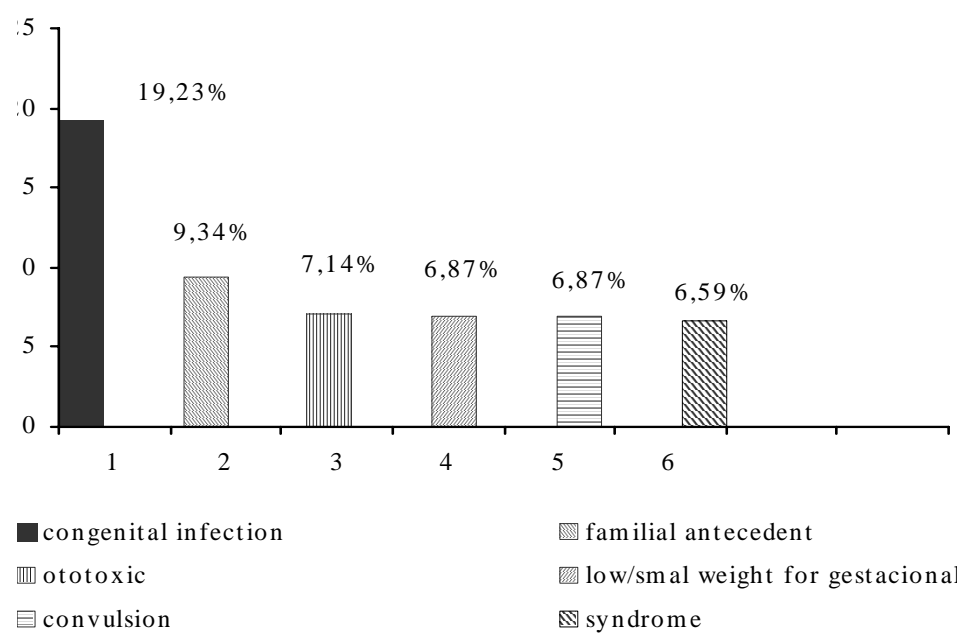

Programa de triagem auditiva neonatal: associação entre perda auditiva e fatores de risco in the verbal category in the area of Human Communication Disorders at the Prize Barreto/2004Federal University of São Paulo- UNIFESP

This research is a retrospective study, carried through with handbooks of 1696 newborns born in the years of 2000, 2001 and 2002, pertaining to the Program of

Prevention and Precocious Identification of peripheral and central auditory alterations of the Hospital São Paulo of the Federal University of São Paulo, located in the south region of the city of São Paulo.

The protocols of the 1696 neonates were distributed in two groups: Group I, formed for 648 newborns prior-term from the neonatal Intensive Care Unit (NICU) being 343 males 305 females, and Group II, formed for 1048 newborns, being 550 males and 498 females.

The data collection was carried through from the survey of handbooks of the children born in the selected years, analyzing:

. data of anamneses and hospital handbook, identifying presence of risk factors for the hearing (Azevedo, 2004). In group I the relative data to the weight of birth, gestational age and relation of weight and gestational age were also raised.

.result in the examination of Transient Otoacoustic Emissions (TOAE), considering presence of reply when the signal/noise rate was above $3 \mathrm{~dB}$ in 1000 $\mathrm{Hz}$ and/or $1500 \mathrm{~Hz}$ and above of $6 \mathrm{~dB}$ in the frequencies of $2000 \mathrm{~Hz}$ the $4000 \mathrm{~Hz}$. Stability of the sounding lead above of $70 \%$ and reproductive answers superior to $50 \%$

- presence of Cochlea Palpebral Reflex (CPR), researched with the "agogo" at $100 \mathrm{~dB}$ NPS (Azevedo, 2004).

. final audiology diagnosis.

The collected information were typed and placed in a spread sheet in the Excel program, separating prior term children pertaining to the Intensive Care, of the term children pertaining to the Joint Lodging. These spread sheets were directed for the statistical analysis (data edition, survey of significant relations between the variable and analysis of frequency) to elaboration of tables and figures. For better statistical analysis, the variables presence of Cochlea Palpebral Reflex (CPR) and Transient Otoacoustic Emissions (TOAE) were analyzed by ear. The used statistical tests were the Accurate Test of Fischer and the Logistic Regression, and the adopted level of significance $\mathrm{p}$ was 0,05 ( $\mathrm{p}<0,05)$ or $5 \%$. 


\section{Results}

The distribution of the found risk factors in the group of term newborns (TNB) and prior term newborn (PTNB) is presented in figures 1 and 2 .

There was greater occurrence of Transient Otoacoustic Emissions (TOAE) and Cochlea Palpebral Reflex (CPR) in the group of term newborns in relation to the in prior term newborn as it may be observed in Tables 1 and 2 .

Statistical significant correlation was observed between the presence of TOAE and CPR and the gestational age. As lesser the gestational age the bigger was the possibility to present absence of TOAE and CPR (Tables 3 and 4).

Among the children with very low weight there was less occurrence of TOAE, being statistically significant the right side (Table 5). There was no statistically significant difference in relation to the presence of the CPR (Table 6).

There was no correlation statistically significant between the presence of TOAE and CPR and the relation weight and gestational age (Tables 7 and 8 ).
TABLE 1. Occurrence of Transient Otoacoustic Emissions (TOAE), in Groups I and II.

\begin{tabular}{c|cccc}
\hline TOAE & \multicolumn{2}{|c}{$G I(P T N B-N I C U)$} & \multicolumn{2}{c}{$G I I(T N B)$} \\
\hline & $n$ & $\%$ & $n$ & $\%$ \\
\hline presence & 462 & 79.79 & 855 & 86.03 \\
absentee & 119 & 30.85 & 151 & 13.97 \\
\hline Total & 581 & 100 & 1006 & 100 \\
\hline
\end{tabular}

Subtitle: $n$ number

TABLE 2. Occurrence of Cochlea Palpebral Reflex (CPR), in Groups I and II.

\begin{tabular}{c|cccc}
\hline CPR & \multicolumn{2}{|c}{ GI(PTNB- NICU) } & \multicolumn{2}{c}{ GII (TNB) } \\
\hline & $n$ & $\%$ & $n$ & $\%$ \\
\hline presence & 544 & 85.53 & 898 & 86.34 \\
absentee & 92 & 14.46 & 142 & 13.66 \\
\hline Total & 636 & 100 & 1040 & 100 \\
\hline
\end{tabular}

TABLE 3. Distribution of prior term newborns according to Otoacoustic Emissions and Gestational Age (GA).

\begin{tabular}{|c|c|c|c|c|c|c|c|c|}
\hline \multirow[b]{2}{*}{ RE } & \multirow[b]{2}{*}{$\begin{array}{l}\mathrm{GA} \\
>30 \mathrm{~s} \\
<=30 \mathrm{~s}\end{array}$} & \multicolumn{2}{|c|}{ presence } & \multicolumn{2}{|c|}{ absentee } & \multirow{2}{*}{\begin{tabular}{|l|} 
Total \\
$\mathrm{n}$ \\
240 \\
102 \\
342 \\
\end{tabular}} & \multicolumn{2}{|l|}{ P- Valor } \\
\hline & & $\begin{array}{l} \\
204 \\
77 \\
281 \\
\end{array}$ & $\begin{array}{l}\% \\
85 \\
75.49\end{array}$ & $\begin{array}{l}\mathrm{n} \\
36 \\
25 \\
61 \\
\end{array}$ & $\begin{array}{l}\% \\
15.00 \\
24.51\end{array}$ & & $0.0358 *$ & $\mathrm{OR}=1.84$ \\
\hline LE & $\begin{array}{l}>30 \mathrm{~s} \\
<=30 \mathrm{~s}\end{array}$ & $\begin{array}{l}200 \\
74\end{array}$ & $\begin{array}{l}82.30 \\
72.55\end{array}$ & $\begin{array}{l}43 \\
28\end{array}$ & $\begin{array}{l}17.30 \\
27.45\end{array}$ & $\begin{array}{l}243 \\
102\end{array}$ & $0.0411^{*}$ & $\mathrm{OR}=1.76$ \\
\hline Total & & 274 & & 71 & & 354 & & \\
\hline
\end{tabular}

Subtitle: OR- Odds Ration

TABLE 4. Distribution of prior term newborns by Cochlea Palpebral Reflex and Gestational Age (GA).

\begin{tabular}{|c|c|c|c|c|c|c|c|c|}
\hline \multirow[b]{2}{*}{ Total } & & \multicolumn{2}{|c|}{ presence } & \multicolumn{2}{|c|}{ absentee } & Total & P- Valor & \\
\hline & $\begin{array}{l}\text { Weight } \\
>1500 \mathrm{~g} \\
<=1500 \mathrm{~g}\end{array}$ & $\begin{array}{l}\mathrm{n} \\
236 \\
138 \\
374 \\
\end{array}$ & $\begin{array}{l}\% \\
83.10 \\
77.53\end{array}$ & $\begin{array}{l}\mathrm{n} \\
48 \\
40 \\
88 \\
\end{array}$ & $\begin{array}{l}\% \\
16.90 \\
22.47\end{array}$ & $\begin{array}{l}\mathrm{n} \\
284 \\
178 \\
462 \\
\end{array}$ & 0.1383 & \\
\hline LE & $\begin{array}{l}>1500 \mathrm{~g} \\
<=1500 \mathrm{~g}\end{array}$ & $\begin{array}{l}237 \\
137\end{array}$ & $\begin{array}{l}83.16 \\
75.69\end{array}$ & $\begin{array}{l}48 \\
44\end{array}$ & $\begin{array}{l}16.84 \\
24.31\end{array}$ & $\begin{array}{l}285 \\
181\end{array}$ & 0.0487* & $\mathrm{OR}=1.58$ \\
\hline Total & & 374 & & 92 & & 466 & & \\
\hline
\end{tabular}


Pró-Fono Revista de Atualização Científica, v. 19, n. 2, maio-ago. 2007

TABLE 5. Distribution of prior term newborn according to TOAE and weight at birth.

\begin{tabular}{|c|c|c|c|c|c|c|c|c|}
\hline \multirow[b]{2}{*}{ Total } & & \multicolumn{2}{|c|}{ presence } & \multicolumn{2}{|c|}{ absentee } & \multirow[b]{2}{*}{$\begin{array}{l}\text { Total } \\
\mathrm{n} \\
284 \\
178 \\
462\end{array}$} & \multirow{2}{*}{\multicolumn{2}{|c|}{\begin{tabular}{|l|} 
P- Valor \\
0.1383
\end{tabular}}} \\
\hline & $\begin{array}{l}\text { Weight } \\
>1500 \mathrm{~g} \\
<=1500 \mathrm{~g}\end{array}$ & $\begin{array}{l}\mathrm{n} \\
236 \\
138 \\
374\end{array}$ & $\begin{array}{l}\% \\
83.10 \\
77.53\end{array}$ & $\begin{array}{l}\mathrm{n} \\
48 \\
40 \\
88\end{array}$ & $\begin{array}{l}\% \\
16.90 \\
22.47\end{array}$ & & & \\
\hline LE & $\begin{array}{l}>1500 \mathrm{~g} \\
<=1500 \mathrm{~g}\end{array}$ & $\begin{array}{l}237 \\
137\end{array}$ & $\begin{array}{l}83.16 \\
75.69\end{array}$ & $\begin{array}{l}48 \\
44\end{array}$ & $\begin{array}{l}16.84 \\
24.31\end{array}$ & $\begin{array}{l}285 \\
181\end{array}$ & 0.0487* & $\mathrm{OR}=1.58$ \\
\hline Total & & 374 & & 92 & & 466 & & \\
\hline
\end{tabular}

TABLE 6. Distribution of prior term newborn according to Cochlea Palpebral Reflex and weight at birth.

\begin{tabular}{|c|c|c|c|c|c|c|c|}
\hline \multirow[b]{2}{*}{ Total } & \multirow[b]{2}{*}{$\begin{array}{l}\text { Weight } \\
>1500 \mathrm{~g} \\
<=1500 \mathrm{~g}\end{array}$} & \multicolumn{2}{|c|}{ presence } & \multicolumn{2}{|c|}{ absentee } & \multirow{2}{*}{$\begin{array}{l}\text { Total } \\
\mathrm{n} \\
310 \\
192 \\
502 \\
\end{array}$} & \multirow{2}{*}{\begin{tabular}{|l} 
P- Valor \\
1.000
\end{tabular}} \\
\hline & & $\begin{array}{l}\mathrm{n} \\
235 \\
165 \\
430 \\
\end{array}$ & $\begin{array}{l}\% \\
85.48 \\
85.94\end{array}$ & $\begin{array}{l}\mathrm{n} \\
45 \\
27 \\
72 \\
\end{array}$ & $\begin{array}{l}\% \\
14.42 \\
14.06 \\
\end{array}$ & & \\
\hline \multirow{2}{*}{$\mathbf{L E}$} & $>1500 \mathrm{~g}$ & 268 & 86.45 & 42 & 13.55 & 310 & \multirow[t]{2}{*}{0.6928} \\
\hline & $<=1500 \mathrm{~g}$ & 163 & 84.90 & 29 & 15.10 & 192 & \\
\hline Total & & 431 & & 71 & & 502 & \\
\hline
\end{tabular}

TABLE 7. Distribution of prior term newborns according to Transient Otoacoustic Emission and Relation weight and gestational age.

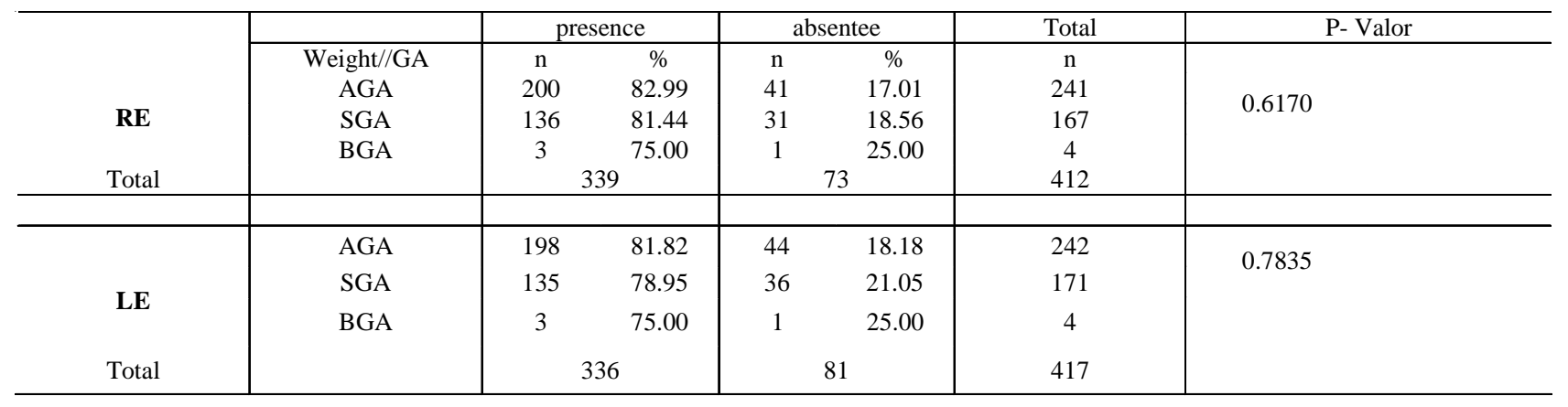

TABLE 8. Distribution of prior term newborns according to Cochlea Palpebral Reflex and Relation weight and gestational age.

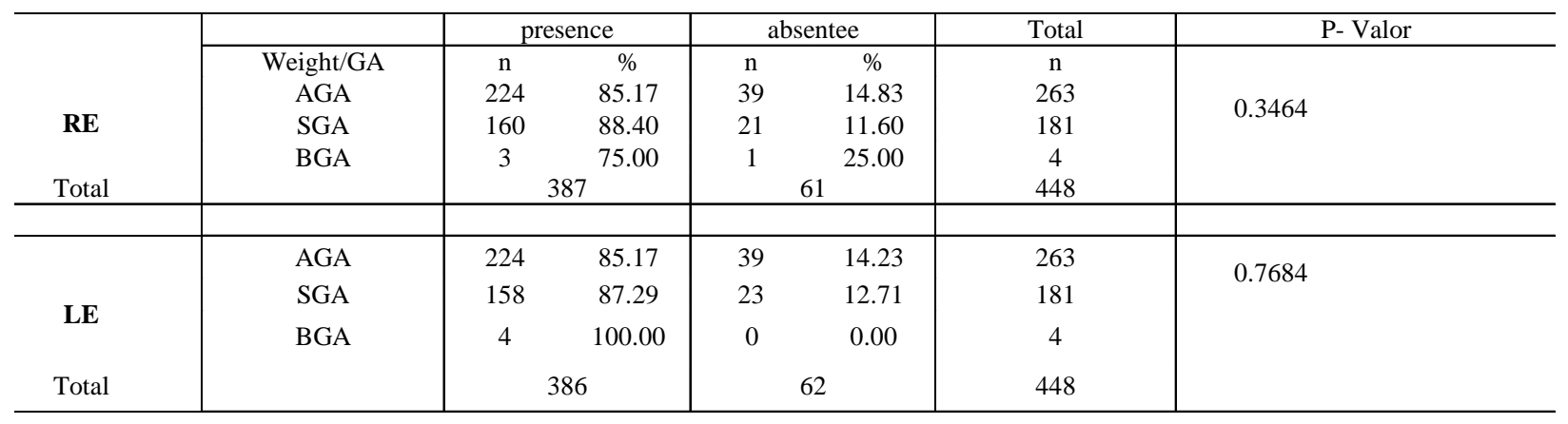


It was observed bigger prevalence of conductive alterations $(13 \%)$ in relation to the sensorioneural hearing loss (6\%) (Figure 3) in the general population, as well as in both the groups (Figure 4). There was suspicion of alteration of the central auditory system in 5, $8 \%$ of the prior term newborns and $3.3 \%$ of the term newborns (Figure 4 ).

There was statistically significant relation between presence of auditory alterations and the groups of prior term and term newborns ( $\mathrm{p}=$ $0,0106)$. The possibility of a term born child to have auditory alteration is 1,35 times bigger that a term born child (Figure 4 ).

The sensorioneural hearing loss was identified in $0,82 \%$ of term newborns and $3.1 \%$ of prior term newborn with statistically significant difference between the groups $(p=0,0014)$, being the possibility of a prior term newborn to have hearing loss is 1,82 times bigger that a term newborn (Figure 5).

It was tried to verify if the TOAC absence would be related with the presence of determined risk factors for hearing loss. In term newborns there was significant correlation between failing at the hearing screening and the prior family risk factors and presence of syndrome. The newborn with familial predecessor of hearing loss will have 7 times more chance to fail in the TOAE of the right side. If the child presents syndrome signals she/ he will have 37 times more possibility to fail on both the sides (Tables 9 and 10).

In the sequence, it was verified correlation between the final diagnosis and the risk factors. In the population of term children there was statistically significant correlation between the presence of syndrome and hearing loss, being 13 times bigger the possibility of a child with syndrome to present hearing loss (Table 11).

Among the prior term children there was no correlation between risk factor and hearing loss.
FIGURE 3. Prevalence of the Auditory Alterations in the general population.

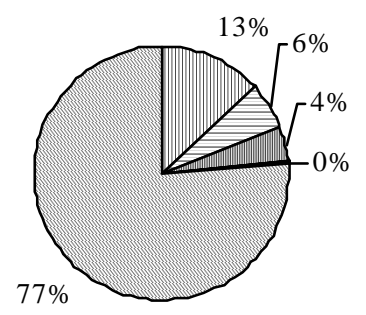

四conductive 目neurossensorial $⿴ 囗 十$ central $\square$ neuropatia $\square$ normal

FIGURE 4. Prevalence of auditory alterations for each Group.

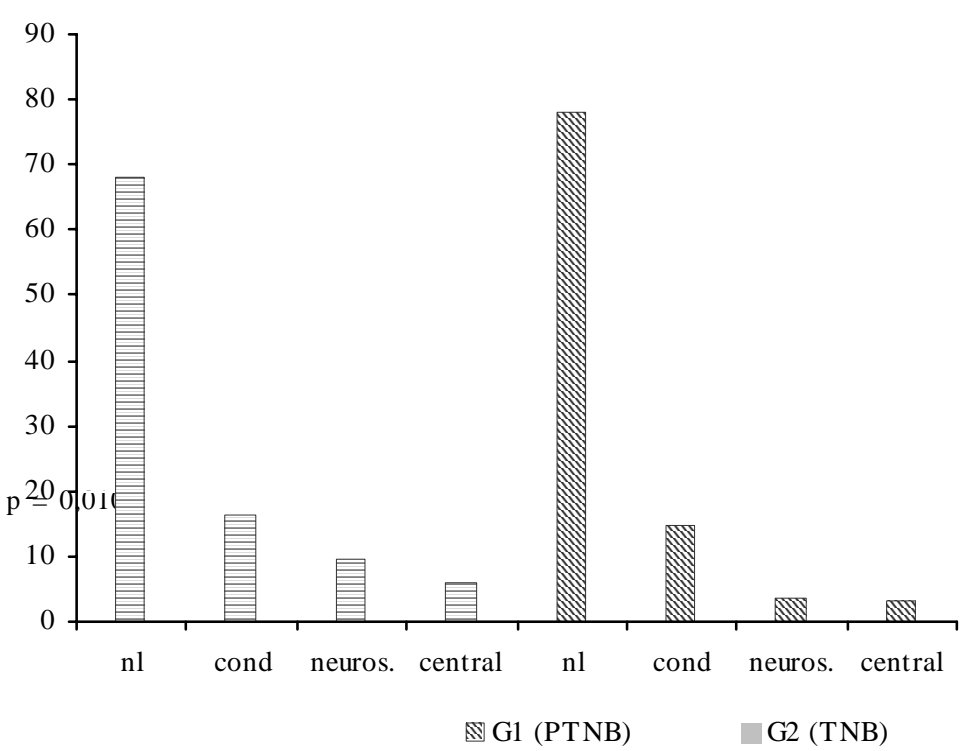

FIGURE 5. Prevalence of sensorioneural hearing loss in Group I and Group II in relation to the general population

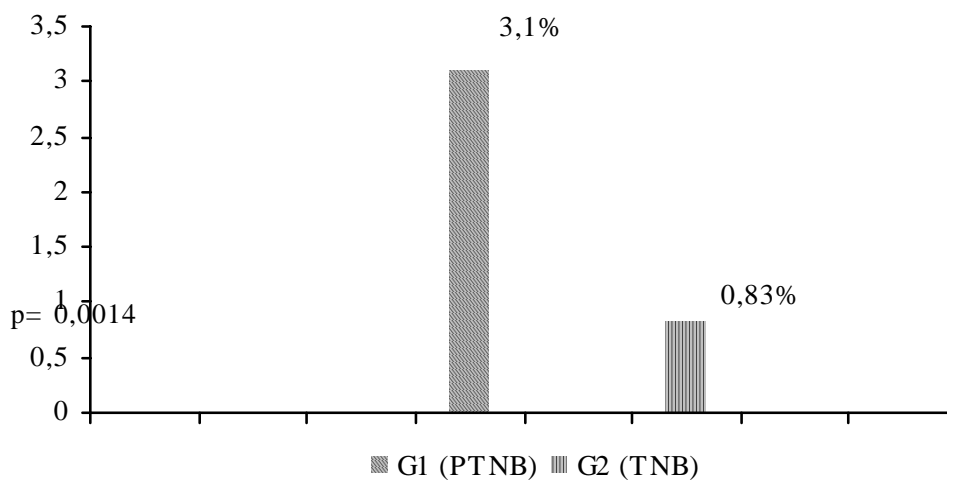


TABLE 9. Distribution of the risks according to Otoacoustic Emissions in the right ear.

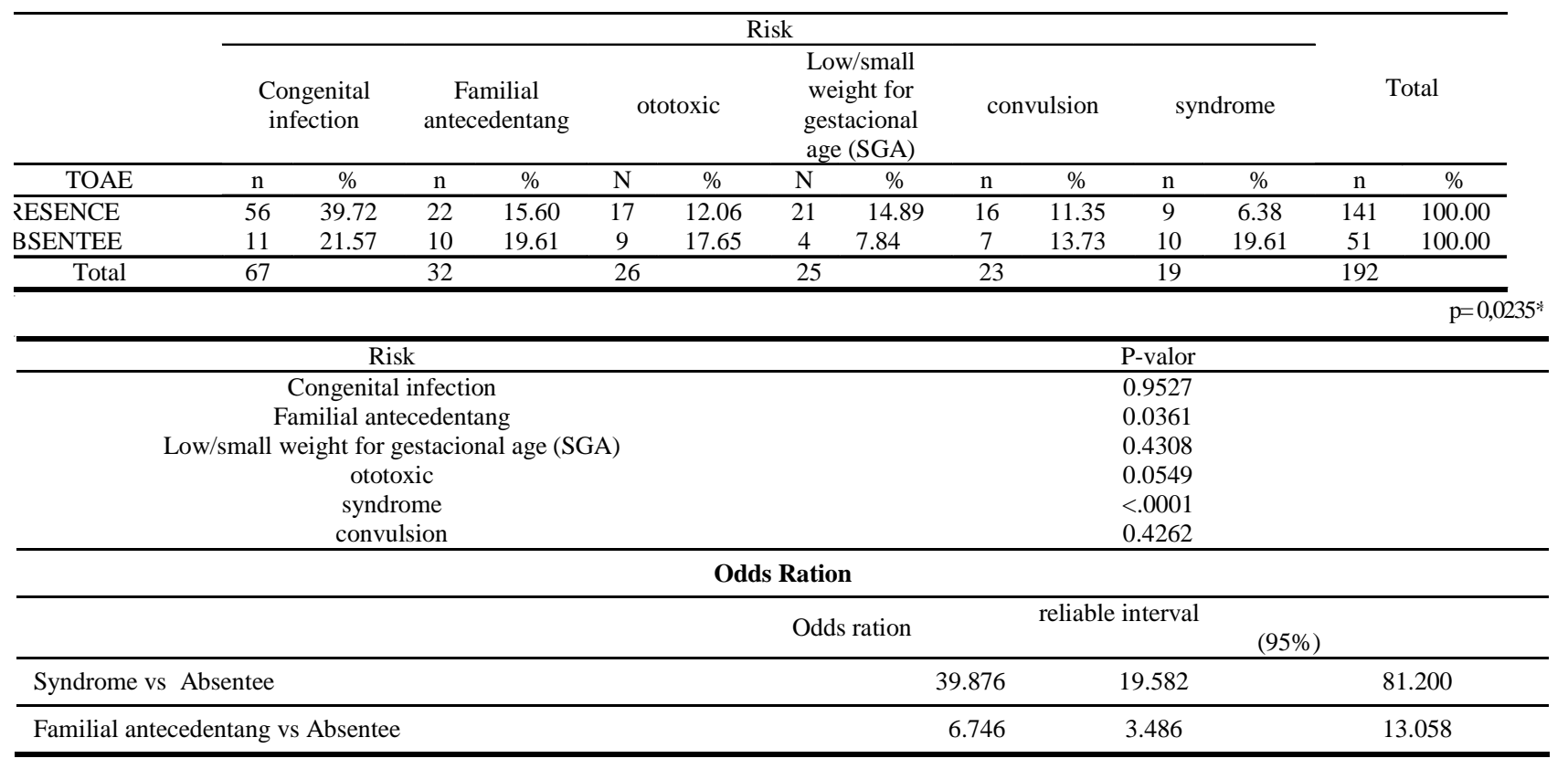

TABLE 10. Distribution of the risks according to Otoacoustic Emissions in the left ear.

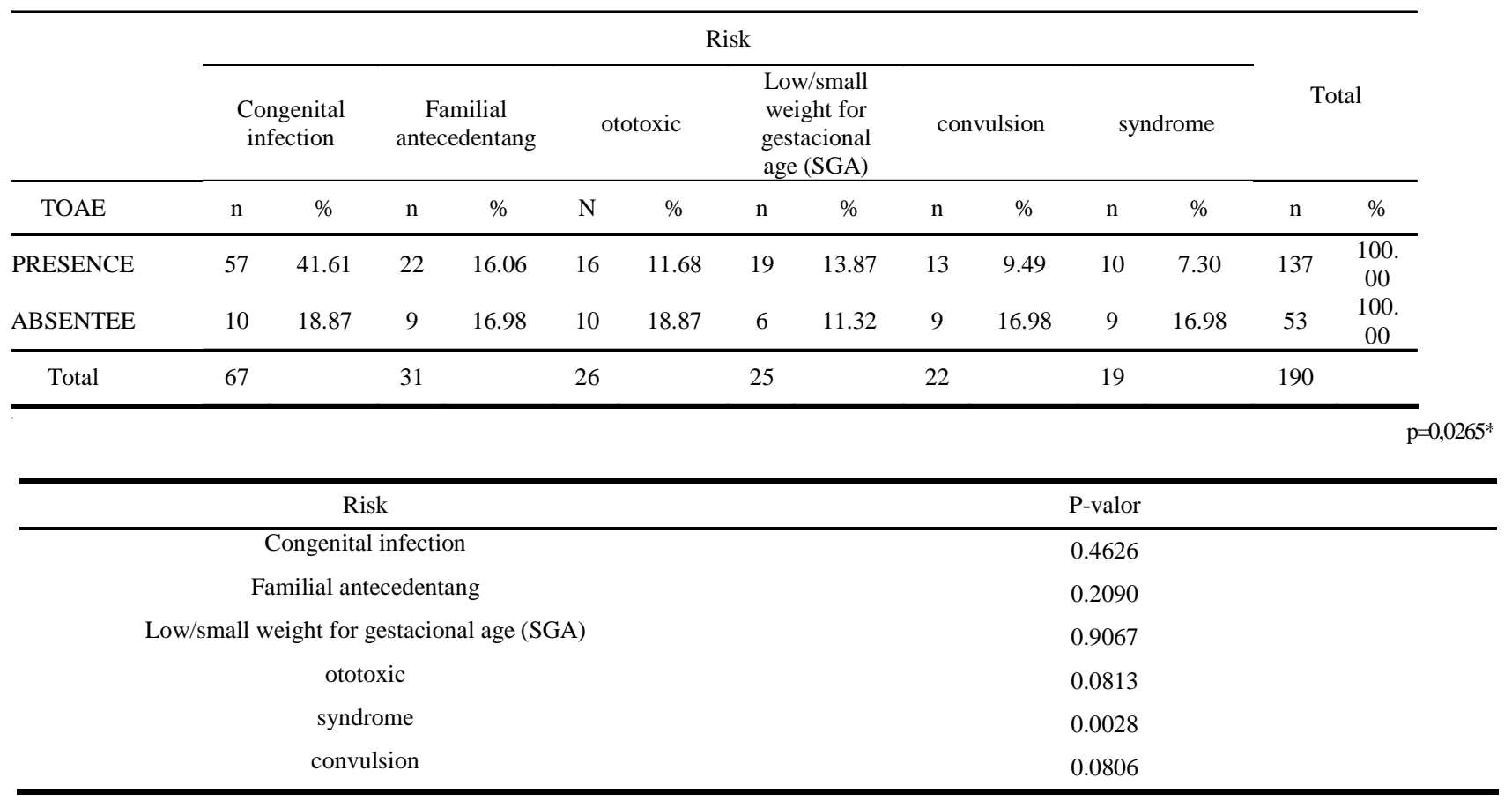

Odds Ration

\begin{tabular}{lccc}
\hline & Odds Ration & \multicolumn{2}{c}{ reliable interval (95\%) } \\
\hline & & & \\
\hline Syndrome vs Absentee & 37.070 & 24.901 & 55.185 \\
\hline
\end{tabular}


TABLE 11. Distribution of the risks as diagnostic.

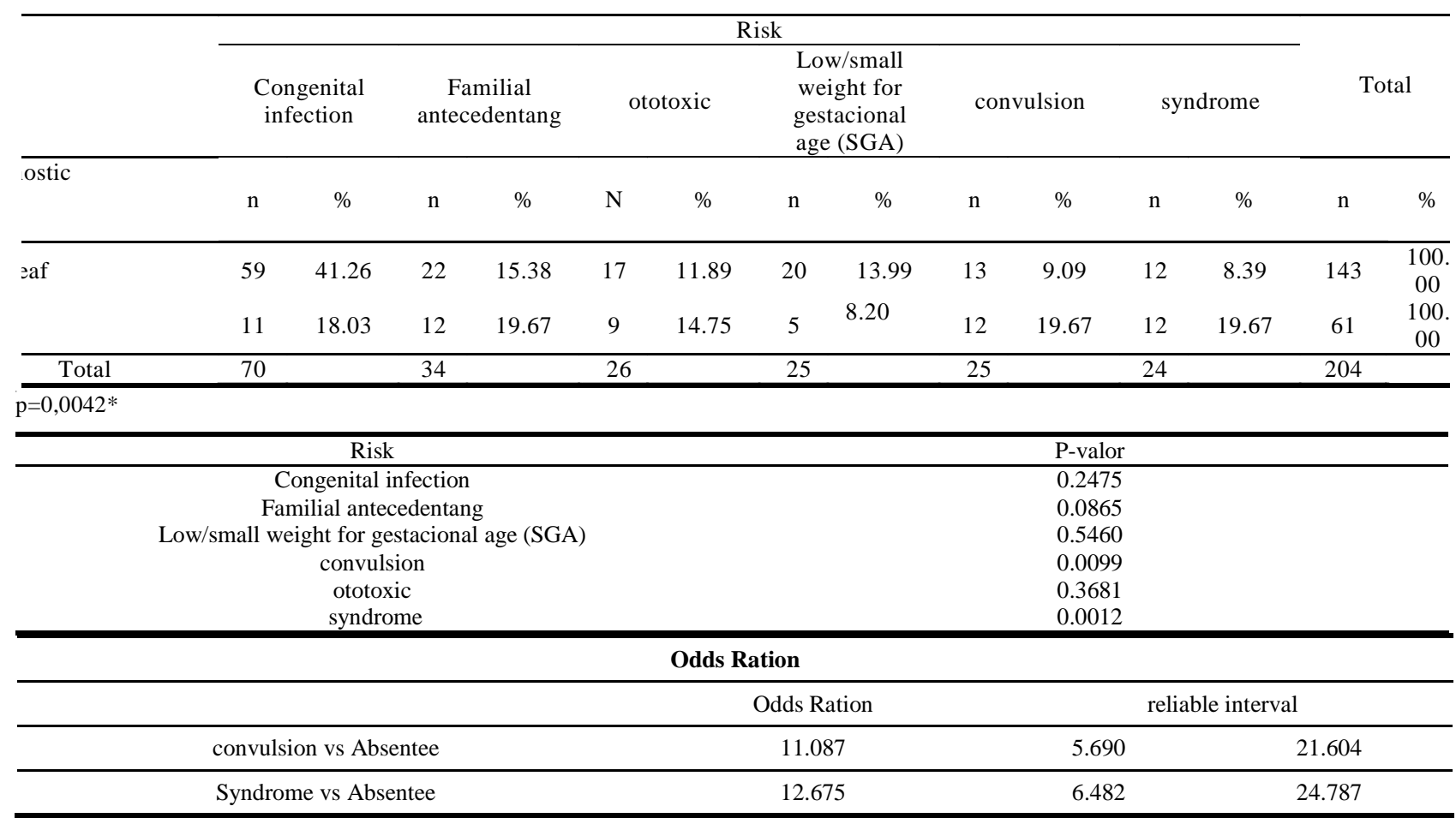

\section{Discussion}

An analysis of the results obtained in the study was carried through, comparing them with consulted literature.

In the present study the main risk factors for hearing loss in the group of prior term and term NB were raised (Figures 1 and 2). The more frequent risk factors for auditory deficiency in prior term NB were the low/small weight for gestational age (SGA), followed by ototoxic and mechanical ventilation. For the term NB, the more frequent risk factors for the auditory alterations were congenital infection, familial antecedent, ototoxic and low/ small weight for gestational age (SGA). The obtained results were similar to the one found in the study of Azevedo et al. (2004), where the following risks for prior term born children were found in the Verador Jose Storópolli Hospital: ototoxic, newborn with very low weight or SGA, mechanical ventilation and congenital infection. In term newborns, the most frequent risks were: congenital infection, familial antecedent of hearing loss and newborns with very low weight or SGA and asphyxia.

Roman et al. (2001) observed that the most frequent auditory risk was familial antecedent of auditory deficiency, followed by congenital infection.

Korres et al. (2005) found as more frequent risk factors for auditory deficiency in a population of low risk newborns, familial history of hearing impairment and congenital anomalies, while that in the population of high risk newborns they found ototoxic, mechanical ventilation for more than 24 hours, prematurity and low weight.

Lonsbury-Martin et al. (2001) observed reduction of the TOAE in patients submitted to the therapy with ototoxic for more than 12 days.

Khairi et al. (2005) found the following risk factors for hearing impairment in a population of newborn of high risk: craniofacial malformations, low weight at birth, ototoxic, syndromes associated with the hearing loss and hyperbilirrubinemy to the transfusion level.

De Capua et al. (2003) evaluating a population of 532 newborns being 84 of risk found a statistical significant relation between hearing impairment and the following risk factors with its respective reasons of possibility: mechanical ventilation for longer than 10 days $(14,8)$, severe neonatal asphyxia $(5,8)$ and ototoxic medication $(4,5)$. 
It was also studied whether there was a relation between the gestational age, the weight at birth and the relation weight and gestational age with the presence of the Otoacoustic Emissions and the Cochlea Palpebral Reflex.

It was observed a statistically significant relation between presence of Otoacoustic Emissions and gestational age for both the ears (Table 3), that is, as smaller the gestational, bigger the possibility to have absent TOAE. The same occurred in relation to the Cochlea Palpebral Reflex, that is, as smaller the gestational age of the child, the greater the possibility to absent the CPR (Table 4). This fact can be related to the presence of vernix in the external acoustic meato. Doyle et al. (1997) affirmed that there are two conditions that can produce temporary hearing loss in newborns: vernix or debris in the external acoustic meato and fluid in the middle ear. Vernix in the external acoustic meato is a serum substance that coats the skin of newborns and can be seen by the otoscopic examination.

Chang et al. (1993) found $15 \%$ of imperfections in the hearing screening by means of TOAE and verified an increase of the occurrence of "passes", after-cleanness of vernix (from $76 \%$ to $91 \%$ ).

Del Buono et al. (2005) evaluated 50 newborns during $1^{\circ}$ day of life and 80 during

$2^{\circ}$ day, demonstrating that in $2^{\circ}$ day of life there was a significant improvement on test $(\mathrm{P}<0.001)$, and less incidence of artifacts $(\mathrm{P}<0.001)$, concluding that the $2^{\circ}$ day of life is the most appropriate moment to neonatal hearing screening with TOAE.

Doyle et al. (1997) found a prevalence of vernix in the external acoustic meato of $13 \%$ (53 out of 400 ears). They had also observed, difference statistically significant when they compared the percentage of vernix obstructing the meato newborns with less than 24-hours $(14,2 \%)$ and just newborns with more than 24 hours $(11,7 \%)$. Moreover, of the 85 ears that had failed in the hearing screening carried through by these authors, $33(62 \%)$ presented vernix obstructing the external acoustic meato. After cleanness, the authors observed that 22 ears $(67 \%)$ had passed in the second test, moving the percentage of "pass" ( $79 \%$ to $84 \%$ ) found in the population of studied newborns. These same authors in 2000 observed significant improvement in the index of "pass" in the neonatal hearing screening after-cleanness of the meato with withdrawal of vernix. They also detected reduction of the mobility of the tympanic membrane in $22,7 \%$ (90/396) of the evaluated ears, demonstrating significant effect in the index of "fail" in the hearing screening for TOAE.

Priner et al. (2003) correlated the fail in the hearing screening for TOAE to the reduction of the mobility of the tympanic membrane caused by the fluid presence in the middle ear, occurring, this way, a temporary conductive hearing loss.

Doyle et al. (2004) told that fails in the screening for TOAE also can be attributed to the alterations of middle ear (secretor otitis) and that the children who present secretor otitis during the neonatal period present bigger risk to develop chronic middle otitis during the first year of life.

In the present study, it was also observed the relation between TOAE and weight at birth, being statistically significant to the right. There was not significant relation between presence of CPR and weight at birth. Uchôa et al. (2003) evaluating the prevalence of newborns auditory alterations in of very low weight by means of the otoacoustic emissions by products of distortion, complemented by audiometric test of cerebral trunk, identified $6.3 \%$ hearing impaired. According to Segre (2003), the group of newborns with very low weight, frequently accumulates some risk factors. Ari- Even Roth et al. (2006) carried through neonatal hearing screening by means of the research of TOAE in 346 newborns with low weight and observed that in this population there is a bigger fail index when compared with the newborns with no risk.

It was observed the occurrence of CPR more than in $85 \%$ of the population.

There was not statistically significant relation between CPR presence and TOAE and relation between weight and gestational age as can be observed in Tables 7 and 8

For the NB of Group I (prior term), the prevalence of auditory alterations was $32,05 \%$, while for the NB of Group II (term) the prevalence was $22,03 \%$, presenting a difference statistically significant $(\mathrm{p}=0,0106)$, that is, the possibility of a prior term NB to have an auditory alteration is 1,35 times bigger than the possibility of a term NB (Figure 4).

The prevalence of sensorioneural hearing loss found in general population was $5,97 \%$, being the bigger occurrence in prior term newborns (Figure 3 ). The prevalence of sensorioneural hearing loss in the Group of prior term NB was 3,1\% and in the Group of term NB was $0,82 \%$ with difference statistically significant $(p=0,0014)$, that is, the possibility of a prior term NB to have a sensorioneural hearing loss is almost twice $(1,82)$ the chance of a term NB (Figure 5). 
Khairi et al. (2005) carried through hearing screening in 401 high risk newborns, and found a prevalence of $1 \%$ of hearing loss.

Habib et al. (2005) studied a population of 10943 newborns from Saudi Arabia and found an incidence of $0,18 \%$ of sensorioneural hearing loss.

Wroblewska - Seniuk et al. (2005) found a prevalence of $3,56 \%$ of hearing loss in newborns from common nursery when compared to $24,9 \%$ of high risk newborns.

In the study "the Project of Rhode Island" (White, Vohr and Behrens, 1993) it was obtained a prevalence of sensorioneural hearing loss in term newborns of $0,26 \%$, which indicates an inferior prevalence to the obtained in this study. However, it must be taken into consideration that the sample of term newborns of the present study originates from a low income population and, consequently, with little access to health care. In relation to the prevalence of sensorioneural hearing loss in the group of IC prior terms, it was also smaller $(2,33 \%)$ in the "Project of Rhode Island", however, not very distant from the one found in the present study $(3,1 \%)$. Despite this difference, the results of the present study agree to other cited studies on literature. The prevalence of hearing loss in the group of prior term IC newborns is always bigger that in the group of term newborns, because of the fact that the first group have greater propensity for risk factors for hearing loss. Garcia et al. (2002), studying 43 term children and 79 prior term children, observed that premature newborns fail more in the answers of the otoacoustic emissions. These authors found sensorioneural hearing loss for 16 ears out of 1000 .

This corroborates with the findings of Allen et al. (1999) that found 2 to $4 \%$ of hearing loss in a population of risk newborns and $0.3 \%$ for the population of newborns with no risk. Roman et al. (2001) also observed a prevalence of hearing loss of 3,1\%. De Capua et al. (2003) evaluated 532 newborns, being 84 of high risk, observed prevalence of hearing loss in newborns with one or indicating of risk (24,5:1000), superior to the one found in newborns without risk (2,2:1000), which corroborates with the findings of present study. Azevedo et al. (2004) also found similar prevalence to the one in the study prior term newborns $(2,9 \%)$. Iñiguez et al. (2004) evaluated 472 newborns with risk factors for hearing loss, 441 had made TOAE in which was observed $3 \%$ of sensorioneural hearing loss and $5 \%$ of conductive hearing loss.

The obtained prevalence of conductive hearing loss was $12,86 \%$ (Figure 3). The prevalence of conductive alterations exists because of the fact of the presence of vernix in this population and because of the great incidence of problems on the middle ear, mainly otitis. The age of bigger occurrence of problems on the middle ear is between 4 and 12 months (Saes, 2005). Garcia et al. (2002) found a prevalence of conductive hearing loss in a population of 157 newborn of 29 ears out of 1000. Doyle et al. (2004) related that fails on the hearing screening for TOAE also can be attributed to the alterations of the middle (secretor otitis) and that the children who present secretor otitis during the neonatal period present bigger risk to develop chronic middle otitis during the first year of life. Boone et al. (2005), evaluating the presence of alterations of middle ear in a population of 76 newborns that failed in the hearing screening, identified $64,5 \%$ of children with middle otitis, and from these, $34.7 \%$ needed ventilation tubes.

It was found in the present study for suspicion of central alteration, $4.28 \%$ of the newborns (Figure 3 ), inferior percentage than the one found in the study of Azevedo, 1996, in which $12 \%$ of children presented such alteration.

The relation of the main risks for hearing loss found in each Group with the occurrence of the Otoacoustic Emissions and the Cochlea Palpebral Reflex was analyzed.

In Group I, of prior term NB, there was not statistically significant relation, while in Group II, of term NB, there was no statistically significant relation between the risk presence of syndromes $(\mathrm{p}=0,0028)$ and familial antecedent of hearing loss, that is, the possibility of term newborns syndrome to fail in the TOAE is 37 times bigger than that of newborns without this risk.

If the newborn presents familial antecedent of hearing loss he/she will have 7 times more possibility to fail in TOAE in the right ear (Tables 9 and 10). This result corroborates with the study of Wroblewska- Seniuk et al. (2005) in which they found 7,5 times more possibility to fail in TOAE when the risk was familial history of hearing loss followed by congenital malformations (6.7) and low Apgar (5).

Lima (2004) carrying through a study with a similar objective to the one of the present study, however carried through with PEATE, found as main risk factors significantly associates to the hearing loss, familial antecedent alteration for deafness, craniofacial malformation and syndromes.

In the present study it was also verified the correlation of the diagnosis with the risk factors. It 
was observed that amongst the more frequent risks found in term newborns, the risk syndromes $(\mathrm{p}=0,0012)$ had a statistically significant relation with the presence of sensorioneural hearing loss, that is, the possibility term newborns with syndrome to present sensorioneural hearing loss is 13 times bigger than that of term newborns without this risk (Table 11).

In the Group of term children it was not found statistically significant correlations between the diagnosis of deafness and the risk factors. This fact occurred in virtue of the group of prior term newborns to have a great amount and variety of risk factors for hearing loss.

According to the literature, NB with risk factors for hearing impairment, independently of being a term or prior term NB, have greater possibilities to present sensorioneural hearing loss. (White, Vohr and Behrens, 1993; Allen et al., 1999; Romam et al., 2001; Of Capua et al., 2003; Azevedo et al., 2004; Rasp, 2004; Chamber, 2005).

\section{References}

ALLEN, S. G.; BARTLETT, C.; COHEN, N.; EPSTEIN, S.; HANIN, L.; TRENI, K. Maximizing auditory and speech potencial for deaf and hard-of-hearing children proceedings of a clinical roundtable the hearing. Hear J., v. 32, p. 1-16, ago. 1999.

ARI-EVENROTH, D.; HILDESHEIMER, M.; MAAYANMETZGER, A.; MUCH-NIK, C.; HAMBURGER, A.; MAZKERET, R.; KUINT, J. Low prevalence of hearing impairment among very low birthweight infants as detected by universal neonatal hearing screening. Arch. Dis. Child Fetal Neonatal Ed., Telhashomer (Israel), v. 91, n. 4, p. 257-262, jul. 2006.

AZEVEDO, M. F. Programa de prevenção e identificação precoce dos distúrbios da audição. In: SCHOCHAT, E. Processamento auditivo. São Paulo: Lovise, 1996. p. 75105.

\section{Conclusion}

As smaller the gestational age ( $<30$ weeks) and the weight at birth $(<1500 \mathrm{~g})$, greater will be the possibility of the child to fail in the hearing screening. There was significant relation between the fail in the hearing screening and the risks syndrome and familial antecedent. The possibility of term newborns with syndrome to fail in the Otoacoustic Emissions is 37 times bigger than the one of term newborns without this risk. If the newborn presents familial antecedent of hearing loss he/she will have 7 times more possibility to fail in the Otoacoustic Emissions in the right ear.

In the prior term newborns of NICU, there was greater occurrence of sensorioneural hearing loss $(3,1 \%)$ than the one observed in the literature.

In the term children there was statistically significant correlation between hearing loss and the risk syndromes. The possibility of a term born child with syndrome to have hearing loss is 13 times bigger than the possibility of a term child without the risk has hearing loss.

There was statistically significant relation between hearing loss and prior term and term newborns. The possibility of prior term newborns to have sensorioneural hearing loss is 1,82 times bigger than the term newborns to have sensorioneural hearing loss.

AZEVEDO, M. F. Triagem auditiva neonatal. In: FERREIRA, L. P.; BEFI-LOPES, D. M.; LIMONGI, S. C. O. Tratado de fonoaudiologia. São Paulo: Rocca, 2004. p. 604-616.

AZEVEDO, R. F.; PASCHOAL, C. P.; AZEVEDO, M. F.; SANTOS, A. M. N.; FÚRIA, C. L. B. Avaliação da implantação de programa de triagem auditiva neonatal em hospital de nível secundário. R. Paul Pediatr., São Paulo, v. 22, n. 2, p. 77-83, jun. 2004.

BOONE, R. T.; BOWER, C. M.; MARTIN, P. F. Failed newborn hearing screens as presentation for otitis media with effusion in the newborn population. Int. J. Pediatr. Otorhinolaryngol., Little Rock (USA), v. 69, n. 3, p. 393-397, mar. 2005. 
CÂMARA, M. F. S. Efeito de fármacos ototóxicos na audição de recém nascidos de alto risco. 2005. 168 f. Tese (Doutorado em Ciências) - Departamento de Otorrinolaringologia e Distúrbios da Comunicação Humana, Universidade Federal de São Paulo, São Paulo.

CASTRO JÚNIOR, N. P. C.; MARONE, S. A. M.; ALMEIDA, C. I. R.; REDONDO, M. C. Avaliação audiológica em recém-nascidos. In: CAMPOS, C. A. H.; COSTA, H. O. O. (Ed.). Tratado de otorrinolaringologia. São Paulo: Roca, 2002. p. 441-451.

CHANG, K. W.; VOHR, B. R.; NORTON, S. J.; LEKAS, M. D. External and middle ear status related to evoked otoacoustic emission in neonates. Arch. Otolaryngol. Head Neck Surg., Seatle, v. 119, n. 3, p. 276-282, mar. 1993.

CHAPCHAP, M.; RIBEIRO, F. G. S. M.; SEGRE, C. M. Triagem auditiva neonatal. In: FONSECA, V. R. J. R. M. (Ed.). Surdez e deficiência auditiva: a trajetória da infância à idade adulta. São Paulo: Casa do Psicólogo Livraria e Editora, 2001. p. 59-91.

DE CAPUA, B.; DE FELICE, C.; CONSTANTINI, D.; BAGNOLI, F.; PASSALI, D. Newborn hearing screening by transient evoked otoacusitc emissions: analysis of response as a function of risk factors. Acta Otorhinolaryngol. Ital., Siena (Italy), v. 23, n. 1, p. 1620, feb. 2003.

DEL BUONO, Z. G.; MININNI, F.; DELVECCHIO, M.; PANNACCIULLI, C.; MININNI, S. Neonatal hearing screening during the first and second day of life. Minerva Pediatr., Bari (Italy), v. 57, n. 4, p. 167-172, aug. 2005.

DOYLE, K. J.; BURGGRAAFF, B.; FUJIKAWA, S.; KIM, J.; MACARTHUR, C. J. Neonatal hearing screening with otoscopy, auditory brain stem response, and otoacoustic emissions. Otolaryngol. Head Neck Surg., Iuirne (USA), v. 116, n. 9, p. 597-603, jun. 1997.

DOYLE, K. J.; RODGERS, P.; FUJIKAWA, S.; NEWMAN, E. External and middle ear effects on infant hearing screening teste results. Otolaryngol. Head Neck Surg., CA (USA), v. 122, n. 4, p. 477-481, apr. 2000.

DOYLE, K. J.; KONG, Y. Y.; STROBEL, K.; DALLAIRE, P.; RAY, R. M. Neonatal middle ear effusion predicts chronic otitis media with effusion. Otol. Neurotol., Califórnia (USA), v. 25, n. 3, p. 318-322, may 2004.

GARCIA, C. F. D.; ISAAC, M. L.; OLIVEIRA, J. A. A. Emissões otoacústicas transitórias: instrumento para detecção precoce de alterações auditivas em recém nascidos a termo e pré termo. R. Bras. de Otorr., v. 68, n. 3, p. 344-352, maio-jun. 2002.

IÑIGUEZ, R. C.; CEVO, T. E.; FERNÁNDEZ, F. L.; GODOY, C. B.; IÑIGUEZ, R. S. Detección precoz de pérdida auditiva en niños con factores de riesgo. $R$. Otorrinolaringol. Cir. Cabeza. Cuello, Santiago, v. 64, n. 2, p. 99-104, ago. 2004.

HABIB, H. S.; ABDELGAFFAR, H. Neonatal hearing screening with transient evokes otoacustic emissions in Western Saudi Arabia. Int. J. Pediatr. otorhinolaryngol., Jeddah (Saudi Arabi), v. 69, n. 6, p. 839-842, jun. 2005.
KHAIRI, M. D.; DIN, S.; SHAHID, H.; NORMASTURA, A. R. Hearing screening of infants in neonatal unit, Hospital Universiti Sains malaysia using transient evoked otoacustic emissions. J. Laryngol. Otol., Kelantan (Malaysia), v. 119, n. 9. p. 678-683, sep. 2005.

KORRES, S.; NIKOLOPOULOS, T. P.; KOMKOTOU, V.; BALATSOURAS, D.; KANDILOROS, D.; CONSTANTINOU, D.; FEREKIDIS, E. Newborn hearing screening: effectveness, importance of high-risk factors, and characteristics of infants in the neonatal intensive care unit and well- baby nursy. Otol. Neurotol., Athens (Greece), v. 26, n. 6, p. 1186-1190, nov. 2005.

LIMA, G. M. L. Análise da triagem auditiva por audiometria automática de tronco encefálico de recém-nascidos internados em unidade de cuidados intensivos e intermediários. 2004. 80 f. Tese (Mestrado em Saúde Mental) - Faculdade de Ciências Médicas, Universidade Estadual de Campinas, São Paulo.

LONSBURY-MARTIN, B. L.; MARTIN, G. K.; TELISCHI, F. F. Emissões otoacústicas na prática clínica. In: MUSIEK, F. E.; RITELMANN, W. F. Perspectivas atuais em avaliação auditiva. São Paulo: Manole, 2001. p. 323-341.

ROMAN, P. R.; RAMOS, G. T.; MORILlO, M. C.; SANCHES, S. L.; LOPEZ, R. V. Deteccion precoz de hipoacusias em recien nascidos mediante otoemissiones acústicas on echocheck. An. Esp. Pediatr., v. 54, p. 283289, 2001.

PRINER, R.; FREEMAN, S.; PEREZ, R.; SOHMAR, H. The neonate has a temporary conductive hearing loss due to fluid in the middle ear. Audiol. Neurootol., Jerusalém (Israel), v. 8, n. 2, p. 100-110, mar.-apr. 2003.

SAES, S. O.; GOLDBERG, T. B., MONTOVANI, J. C. Secreção na orelha média em lactentes: ocorrência, recorrência e aspectos relacionados. J. Pediatr., Rio de Janeiro, v. 81, n. 2, p. 133-138, mar.-abr. 2005.

SEGRE, C. A. M. Prevalência de perda auditiva em recém nascidos de muito baixo peso. J. Pediatr., Rio de Janeiro, v. 79, n. 2, p. 103-104, mar.-apr. 2003.

UCHÔA, N. T.; PROCIANOY, R. S.; LAVINSKY, L.; SLEIFER, P. Prevalência de perda auditiva em recémnascidos de muito baixo peso. J. Pediatr., Rio de Janeiro, v. 79, n. 2, p. 123-128, mar.-apr. 2003.

WHITE, K. R.; VOHR, B. R.; BEHRENS, R. Universal newborn hearing screenig. Assessm. Project. Sem. Hear., v. 14, n. 1 , p. 18-29, 1993.

WROBLEWSKA-SENIUK, K.; CHOJNACKA, K.; PUCHER, B.; SZCZAPA, J.; GADZINOWSKI, J.; GRZEGOROWSKI, M. The results of newborn hearing screening by means of transient evokes otoacustic emissions. Int. J. pediatr. otorhinolaryngol., Poznan (Poland), v. 69, n. 10, p. 1351-1357, oct. 2005.

YOSHINAGA-ITANO, C.; SEDEY, A. L.; COULTER, B. A.; MEHL, A. L. Language of early and later identified children with hearing loss. Pediatrics, Boulder (Colorado), v. 102, n. 5, p. 1161-1171, nov. 1998. 